\title{
Quatro sambas de Orfeus e um pouco mais
}

\author{
[ Four Orpheus' sambas and something more
}

\section{Marina Bonatto Malka ${ }^{\mathrm{I}}$}

\section{Carlos Augusto Bonifácio Leite ${ }^{2}$}

RESUMO - Este artigo consiste na análise de algumas canções (de Vinicius de Moraes e Tom Jobim) da peça Orfeu da Conceição (I956), de Vinicius de Moraes, e da adaptação da peça ao cinema, Orfeu negro (I959), de Marcel Camus (canções de Vinicius, Tom, Luiz Bonfá e Antônio Maria). Diversos ritmos são encontrados (samba-canção, frevo, pontos de macumba); uma difusão inédita de ritmos brasileiros. Após o filme, as canções se celebrizaram, sendo regravadas pela bossa nova e mimetizadas pelos músicos de jazz americanos nos anos I960. É inegável a importância dos álbuns, consagrando principalmente Vinicius de Moraes no panorama internacional. Neste artigo observa-se a diferença entre as canções dos álbuns e as que surgiriam a seguir, como uma das raízes primordiais da música popular brasileira das décadas seguintes. PALAVRASCHAVE - Samba; Orfeu da Conceição; Orfeu negro; bossa nova. · ABSTRACT This article aims to analyze some songs (of Vinicius de Moraes e Tom Jobim) of play Orfeu da Conceição (of Vinicius de Moraes, I956), and of the play's adaptation for the cinema, Black Orpheus (by Marcel Camus,I959, songs by Vinicius, Tom, Luiz Bonfá and Antônio Maria). These soundtracks are in several rhythms ("sambacanção", frevo, "pontos de macumba”); an unprecedent diffusion of Brazilian rhythms. After the movie, the songs were celebrated, re-recorded by bossa nova musicians, and imitated by American jazz musicians in the 6os. The historical importance of the albums are undeniable, consecrating manly Vinicius de Moraes in the international scene. In this article it is observed the difference between the songs of the albuns and those that would follow in subsequent years. - KEYWORDS - Samba; Orfeu da Conceição; Black Orpheus; bossa nova.

Recebido em 4 de novembro de 2017

Aprovado em 28 de julho de 2018

MALKA, Marina Bonatto; LEITE, Carlos Augusto Bonifácio. Quatro sambas de Orfeus e um pouco mais. Revista do Instituto de Estudos Brasileiros, Brasil, n. 70, p. I04-I20, ago. 2018.

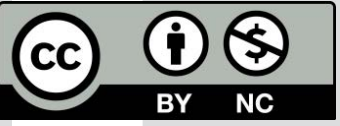

DOI: http://dx.doi.org/Io.II606/issn.23I6-90IX.voi70pIo4-I20

I Universidade Federal do Rio Grande do Sul (UFRGS, Porto Alegre, RS, Brasil).

2 Universidade Federal do Rio Grande do Sul (UFRGS, Porto Alegre, RS, Brasil). 
Filho de Apolo e Calíope, a personagem Orfeu, da mitologia grega, possui o dom da lira, encantando a tudo e a todos com seus versos e sua cítara: "Poucas histórias terão excitado mais o espírito criador dos artistas que o mito grego de Orfeu, o divino músico da Trácia, cuja lira tinha o poder de tocar o coração dos bichos e criar nos seres uma doçura e um apaziguamento" (MORAES, I956). A figura órfica é recorrente na literatura brasileira dos anos I940 e I950 com Carlos Drummond de Andrade nos poemas “Legado", de Claro enigma (I95I), e "Canto órfico", de O fazendeiro do ar (I954), e Jorge de Lima com A invenção de Orfeu (I952). Na França, tampouco passou despercebido pela poesia romântica e simbolista de Mallarmé, pelos filmes de Jean Cocteau, Le sang d'un poète (I930), Orphée (I950) e Le testament d'Orphée (I960), e pelos textos críticos de Maurice Blanchot, em Le regard d’Orphée (I955), e Jean-Paul Sartre com Orphée noir (I948). As reflexões e alterações feitas no mito são bastante diversas e desvelam o ponto de vista e o contexto de cada autor.

Uma das mais celebradas adaptações do mito foi Orfeu da Conceição (tragédia carioca) (I954), do artista Vinicius de Moraes, uma tragédia em três atos que mistura o mito grego de Orfeu com o morro carioca durante o feriado de carnaval. A peça foi encenada no Theatro Municipal do Rio de Janeiro em I956, financiada por Vinicius de Moraes e Raymond Pinto, sendo um grande sucesso de bilheteria e de imensa importância para o teatro brasileiro, pois foi uma das primeiras vezes em que um elenco formado apenas por atores e atrizes negros - mobilizados pelo Teatro Experimental do Negro - TEN, de Abdias Nascimento - subiu no palco do teatro carioca. Além da importância para as discussões sobre a cultura negra no Brasil, a peça de Vinicius contribuiu para o panorama musical da canção popular brasileira. A partir da peça foram feitos dois álbuns musicais: o LP Orfeu da Conceição (I956), da gravadora Odeon, e o CD Black Orpheus (I989), da gravadora Verve/Polygram, mais especificamente da trilha sonora do filme Orfeu negro ou Orfeu do carnaval (I959), uma adaptação da peça de Vinicius de Moraes ao cinema, dirigida pelo francês Marcel Camus3. Há que dizer ainda o óbvio: a peça foi o primeiro encontro dos parceiros Vinicius de Moraes e Tom Jobim, que pouco adiante protagonizariam, somados a João Gilberto, a bossa nova, talvez o

3 Ambos os álbuns foram pesquisados no site Discos do Brasil (2005), de Maria Luiza Kfouri, que contém um dos maiores e bem informados acervos de discografia brasileira. 
mais bem-sucedido gênero musical brasileiro no exterior. Não menos importantes, mas menos óbvios, são o cenário, feito por Oscar Niemeyer - deslumbrante, diziam (CASTELLO, I994, p. I94), mas que causou problemas para encenação adequada da peça em São Paulo -, e a replicação de seu sucesso.

A peça, contudo, não está no centro de nossos interesses - a véspera do núcleo de bossa nova sim, como se verá. Passemos, então, a uma análise geral dos álbuns e de algumas canções em específico, presentes nos dois discos, e de como elas podem ser entendidas à luz de um decisivo momento na história da música popular brasileira. A seleção de quais canções analisar foi feita a partir dos comentários de Wagner Homem e Bruno de la Rosa no livro História das canções (2013) e da grande repercussão, nacional ou internacional, de algumas, como é o caso de "Manhã de carnaval” (I959), de Luiz Bonfá e Antônio Maria, por exemplo. Ilustrativamente, "Se todos fossem iguais a você" (I956) é uma canção que foi interpretada por diversos cantores (Gal Costa, Maysa, Nana Caymmi, Vicente Celestino etc.), sendo sempre retomada, o que depõe sobre uma suposta grande importância para a canção popular brasileira; por sua vez, "Mulher, sempre mulher" (I958) é uma canção que faz mais sentido dentro do contexto da peça - no caso, depois da surra que Orfeu dá em Mira - do que fora dela, pouco foi gravada por outros artistas e parece oferecer menos elementos formais a serem analisados dentre as canções dos discos. Acreditamos que esse recorte consiga abarcar o que é de suma importância dentro dos álbuns.

\section{LP ORFEU DA CONCEIÇÃo (I956)}

"Orfeu da Conceição sempre foi um dos trabalhos preferidos de Vinicius", afirma seu principal biógrafo, José Castello (I994, p. I8I). No ano de I942, Vinicius acompanhou o escritor Waldo Frank em incursões por favelas, terreiros e festejos pela capital da República.

Conversa vai, criou-se subitamente em nós, através de um processo por associação caótica, o sentimento de que todas aquelas celebrações e festividades a que vínhamos assistindo tinham alguma coisa a ver com a Grécia, como se o negro, o negro carioca no caso, fosse um negro em ganga - um grego ainda despojado de cultura e de culto apolíneo à beleza, mas não menos marcado pelo sentimento dionisíaco da vida. (MORAES, 20I3, p. 7).

Posteriormente, eles fizeram uma viagem para o Norte e o Nordeste do Brasil e ambos se encantaram com a cultura afro-brasileira, costumes, culinária, candomblés e capoeiras. Foi no carnaval do ano seguinte que Vinicius começou a escrever a peça, durante sua estadia na casa de Carlos Leão, em Niterói. Existe uma anedota de que ele estava relendo um livro de mitologia grega e escutou uma batucada vinda do Morro do Cavalão, quando subitamente teria vindo a inspiração para escrever uma tragédia negra carioca, ou seja, uma mistura do clássico europeu com o brasileiro afrodescendente, criando, assim, um herói negro. O primeiro ato foi escrito nessa noite de carnaval; o segundo, só em I948, quando ele era cônsul em Los Angeles, assim 
como um "primeiro terceiro ato", cujos originais foram perdidos e tiveram de ser reescritos. João Cabral de Melo Neto deu nome à peça e incentivou a inscrição de Orfeu da Conceição para o concurso de teatro do IV Centenário de São Paulo, que ganhou a premiação. Em I956, Raymond Pinto patrocina a encenação da peça, e Lúcio Rangel e Haroldo Barbosa sugerem a Vinicius o nome de Tom Jobim, que tocava nas caves do Rio de Janeiro, como maestro. Outra história: a famosa frase "Tem um dinheirinho nisso?” teria dado início à parceria. Afirma Vinicius na contracapa do LP de Orfeu da Conceição: "Os sambas criados especialmente para a peça, de parceria nossa, constituíram sem dúvida a parte mais agradável do nosso trabalho" (MORAES, I956), tanto que a parceira não se limitou às canções da peça, e continuou por mais sete anos, encerrando-se somente em I962. Quando pensamos na importância da dupla Tom \& Vinicius, não imaginamos que a parceria tenha durado menos de uma década. Estranhamente esquecida por Décio de Almeida Prado em $O$ teatro brasileiro moderno (2009), a peça foi comentada por Sábato Magaldi em Moderna dramaturgia brasileira (20Io). Em trechos como: "Dir-se-ia apenas que Orfeu não havia encontrado no teatro sua forma, ao passo que atingiu no cinema sua exata expressão" (MAGALDI, 20Io, p. 88) e "A peça apresenta cenas soltas de inegável beleza e lamentamos que o autor não tenha organizado melhor a estrutura dramática da história” (MAGALDI, 20Io, p. 90), Sábato demonstra conhecer peça e filme, bem como identifica certa qualidade plástica em Vinicius, que talvez tenha facilitado ou motivado a adaptação do drama para o cinema.

A breve síntese e a atenção de Sábato sobre ela demonstram a importância da peça, escrita de dentro do mundo diplomático brasileiro, ambientada no Rio, premiada em São Paulo, inspirada pelas viagens de Vinicius e do escritor estadunidense Waldo Frank e intitulada pelo também poeta-diplomata, o pernambucano João Cabral de Melo Neto. Não parece exagero propor que aqui o esforço é de integração, o negro, como o grego em ganga, do Itamaraty às favelas cariocas, em muitos sentidos atravessa as esferas da cordialidade brasileira. O esforço de síntese de Vinicius é notável e pode ser colocado na conta da acumulação necessária para o êxito bossa-novista logo em seguida. Na contraluz, inevitavelmente nos perguntamos pelo que ainda se fazia necessário; uma resposta dialética conduziria ao espírito de tempo ideologicamente eufórico maturado pelo desenvolvimentismo brasileiro, que então começava a se acelerar, e à batida de João Gilberto, que não só resfria, domina, precisa e individualiza as escolas de samba ${ }^{4}$ (GARCIA, I999, p. I7), mas também indica que o caminho para o salto se daria pelo ritmo caracteristicamente brasileiro. Uma análise das canções da peça e do filme reforça essa impressão.

O LP de Vinicius de Moraes e Tom Jobim da trilha sonora de Orfeu da Conceição foi gravado pela Odeon, no Rio de Janeiro, em I956. A gravadora era de grande importância para o cenário da música popular brasileira por ter lançado também discos importantes de outros artistas, como Clara Nunes, Carmen Miranda e Dorival

$4 \mathrm{O}$ trabalho do professor Walter Garcia já avançou muito desde essa primeira síntese. No II Seminário de Pós-Graduação Literatura, Sociedade e História da Literatura, em Porto Alegre, maio de 20I7, o pesquisador, analisando gravações e vídeos em que João Gilberto executa canções, expande a análise das contradições, contemplando entoação, gestualidade, projeção sobre a plateia, execução do instrumento. 
Caymmi. A capa do vinil tem a arte do pintor Raimundo Nogueira, e na contracapa há um texto escrito por Vinicius de Moraes e duas fotos, uma de Roberto Paiva (intérprete) e outra de Luiz Bonfá (violão). Os músicos do álbum são: Luiz Bonfá (violão), Tom Jobim (piano) e Orquestra Odeon, composta de 35 músicos (orquestra de câmara), em uma mistura patente de erudito e popular. Os intérpretes são Roberto Paiva e Vinicius de Moraes (este somente em "Monólogo de Orfeu"), e o arranjo e a regência da orquestra são assinados por Tom Jobim. Diz Vinicius, ainda na contracapa do LP: "Antônio Carlos Jobim partiu realmente da Grécia para o morro carioca num desenvolvimento extremamente homogêneo de temas e situações melódico-dramáticas, fazendo no final, quando a cena abre, o samba romper sobre o morro onde se deve processar a tragédia de Orfeu". O vinil é composto de sete canções divididas em duas canções do lado A e cinco canções do lado B, com duração de 2 I minutos e 30 segundos no total. A divisão das canções do lado A e lado B são: "Ouverture" e "Monólogo de Orfeu" (lado A); "Um nome de mulher", "Se todos fossem iguais a você", "Mulher, sempre mulher", "Eu e o meu amor" e "Lamento no morro" (lado B) (INSTITUTO TOM JOBIM, s/d), sendo todas as canções compostas em I956 para a encenação da peça. O álbum não contém a valsa "Eurídice”, o abre-alas da peça, que desfaz o silêncio com o violão, como verificamos no texto e na nota de pé de página colocada por Vinicius, alertando encenadores: "Nesta peça deverá ser tocada, obrigatoriamente a valsa 'Eurídice', de minha autoria” (MORAES, 20I3, p. I9). Talvez "Eurídice" pudesse ser também a primeira canção do álbum, porém foi gravada somente dez anos mais tarde, por Baden Powell (Baden Powell ao vivo no Teatro Santa Rosa, I966) e Toquinho (A Bossa do Toquinho, I966). Essa diferença deixa claro que peça e disco são objetos estéticos distintos, embora se relacionem proximamente.

"Ouverture", composição e arranjo de Tom Jobim, a primeira canção do álbum, tem as duas primeiras partes instrumentais e a última cantada por Vinicius de Moraes, arranjos villa-lobianos de Tom Jobim e orquestra de câmara, violão e batucada do samba. De novo a contracapa: "Com a ideia de se criar uma Ouverture para grande orquestra, que apresentasse os temas principais das personagens [...]". "Ouverture" vai da tragédia à lírica. Sua primeira parte (até r:03) é altissonante, marcada pela presença de certo tratamento "erudito" da orquestra de exaltação do herói que aparecerá na peça. Ela é intercalada por solos de piano, que dão um tom dramático e sublime à canção. Após a anunciação de um herói pela Orquestra Odeon, surge um solo de violão, evidenciando que esse herói é Orfeu, que no mito grego toca cítara e, na peça de Vinicius, o violão, como marca do popular brasileiro, dando início à segunda parte. De acordo com Tereza Almeida, no livro Orfeu do Vinicius (20I5), explica-se o porquê da troca de Vinicius da cítara para o violão: “[...] personificação do personagem na figura de um músico que, ao invés da cítara, toca violão, um instrumento marcadamente popular e capaz de sintetizar a relação das camadas mais baixas da população brasileira com a música" (ALMEIDA apud ROCHA; CRUZ, 20I5, p. 43). Voltando à canção, o solo de violão é prosseguido pela formação instrumental que remete à música de concerto, dessa vez com uma melodia mais branda e melancólica, anunciando um acontecimento infeliz: a morte de Eurídice, a amada de Orfeu. A partir de 4:39 começa a terceira parte. A orquestra de câmara toca a canção "Lamento no morro" (composição de Tom Jobim e Vinicius de Moraes 
e arranjo de Tom Jobim) marcada por maior resguardado sonoro e, depois, em 5:43, a mesma canção ganha um tom efusivo, juntamente com a batucada do samba e o canto de Vinicius de Moraes.

A letra de "Lamento no morro" trata da impossibilidade de esquecer a amada, estando o eu cancional em eterno estado de espera por alguém que não vai voltar. A espera é para se despedir, o que evidencia a desilusão quanto a uma continuidade na relação amorosa. $\mathrm{O}$ fato de a mulher amada ser o seu destino causa essa espera, pois não se poderia fugir do destino do amor verdadeiro. A canção mostra a tristeza de Orfeu pela morte de Eurídice e a necessidade de se despedir da amada, que foi atingida de um punhal, por Aristeu, também apaixonado por ela e enciumado pela relação dela com Orfeu. A busca de Orfeu por Eurídice acontece durante o segundo e o terceiro atos da peça até sua morte pelas bacantes e por Mira, que não aceitavam o amor exclusivo de Orfeu por Eurídice.

Não posso esquecer
O teu olhar
Longe dos olhos meus
Ai, o meu viver
É de esperar
Pra te dizer adeus
Mulher amada
Destino meu
É madrugada

Sereno dos meus olhos já correu.

(Extraído de: MORAES, 20I5, p. 26).

A entoação ${ }^{5}$, contudo, arrefece a disforia marcando ritmicamente as sílabas, como, por exemplo, "longe dos olhos meus", dando certo balanço ao lamento. As curvas ascendentes do fraseado também contrariam a tristeza. $\mathrm{O}$ caso mais evidente é o do verso final, em que "Sereno dos meus olhos já correu", com elevação e alongamento da última sílaba, e, embora o verso queira dizer que o eu cancional já chorou, a entoação nos sugere alguma alegria, ou, ao menos, algum encantamento. Não parece ser ainda o que ouviremos em "Chega de saudade", especialmente pelo intérprete, Roberto Paiva, cujos vibratos e empostação sublinham o sofrimento - curiosamente, "Regra três" (Toquinho e Vinicius de Moraes), gravada pela primeira vez no disco do Phono 73, desdobrará a introdução de "Lamento no morro", arranjada por Tom Jobim. Instaura-se, em nossa leitura, uma tensão entre uma entoação que já caminha para o sofrer sorrindo bossa-novista e uma interpretação, tanto vocal, quanto instrumental, que sublinha o caráter deceptivo da canção. Não à toa, é exatamente nesse espaço que João Gilberto completará a equação principal da bossa nova.

A terceira canção do álbum é provavelmente a mais célebre, “Se todos fossem

5 "Entoação", “disforia”, "curva ascendente”, dentre outros termos, são provenientes do modelo de análise cancional proposto por Luiz Tatit ao longo de diversas obras. Uma síntese desse modelo pode ser encontrada no primeiro capítulo de: TATIT, 2002. 
iguais a você" (composição de Tom Jobim e Vinicius de Moraes, arranjo de Tom Jobim). Trata-se da canção inaugural da parceria de Vinicius e Tom. "Se todos fossem iguais a você”, também com a presença da Orquestra Odeon, é cantada por Roberto Paiva, com a mesma interpretação mais distanciada e grandiloquente, bastante comum na música popular brasileira da década de I950. Já a melodia é abolerada e suave. Na repetição do refrão, a interpretação de Roberto Paiva dá lugar a um coral de homens e outro de mulheres.

"Se todos fossem iguais a você" foi um verdadeiro sucesso, tendo mais de 78 gravações e se popularizando em outros países da América Latina. Vinícius lamenta que "talvez tenha sido justamente esse sucesso o culpado do não acontecimento dos outros sambas da peça Orfeu da Conceição, sobretudo 'Lamento no morro', que eu considero a melhor dessa safra” (MORAES, 2008, p. I37). Em História de canções: Vinicius de Moraes, de Wagner Homem e Bruno de la Rosa, Jobim provoca, talvez agastado com o hit: "Imagine se todo mundo fosse igual à mulher que a gente ama. O mundo seria um saco" (apud HOMEM; DE LA ROSA, 20I3, p. 36). A resposta do Vinicius para a provocação de Tom foi que a poesia não tem razão alguma. A distância entre a racionalidade imaginativa de Jobim e o professado ultrarromantismo de Vinicius, derramado, inclusive, sobre os nove casamentos de sua biografia, constrói uma tensão interessante a ser desenvolvida noutro momento. Da mesma forma que discriminamos a importância da interpretação instrumental e vocal de João Gilberto, também é possível analisar a importância do derramamento de Vinicius para a melodia sofisticada de Jobim, e vice-versa.

A música que aparentemente é uma declaração de amor, a partir da história contada, ganha um sentido diferente, que vai do amor desbragado ao puerilmente patético. A letra da canção narra o mundo ideal em que todo mundo fosse igual à pessoa amada: nele as pessoas cantariam, sorririam, haveria sol e verdade, ou seja, um mundo feliz e perfeito. Indiretamente, constrói-se o idílio amoroso, isto é, o estado de espírito em que vivemos quando estamos apaixonados, esse estado de espírito que transborda o amor pela pessoa amada nas outras pessoas, que se valem dessa visão extasiada de mundo. A entoação reforça o que diz a letra nas grandes curvas melódicas, no alongamento das vogais, na repetição dos motivos cada vez mais agudos, mas com uma precisão elegante, como em "Uma mulher a cantar/ Uma cidade a cantar/ A sorrir, a cantar, a pedir" - passagem que confirma nossa leitura de que o amor pela mulher é o responsável por essa extrapolação de sentimento à cidade, e a todo mundo. Na peça, a canção surge logo depois do emocionante "Monólogo de Orfeu”, com a canção "Modinha" no pano de fundo, ponto alto do relacionamento de Orfeu e Eurídice, quando o casal não consegue ficar um minuto sem se ver.

Vai tua vida

Teu caminho é de paz e amor

A tua vida

É uma linda canção de amor

Abre teus braços e canta a última esperança

A esperança divina de amar em paz 
Se todos fossem iguais a você

Que maravilha viver

Uma canção pelo ar

Uma mulher a cantar

Uma cidade a cantar

A sorrir, a cantar, a pedir

A beleza de amar

Como o sol, como a flor, como a luz

Amar sem mentir, nem sofrer

Existiria a verdade

Verdade que ninguém vê

Se todos fossem no mundo iguais a você.

(Extraído de: HOMEM; DE LA ROSA, 20I3, p. 35).

Em seguida, Mira entra em cena e discute com Orfeu sobre seu novo relacionamento. Dali em diante o destino trágico do casal apaixonado está traçado e não será possível retomar esse momento extático.

Em linhas gerais, é notável o esforço de Vinicius e Tom para produzirem um álbum com canções que dialogam diretamente com a peça, pois as letras falam sobre a imensidão do amor e a melancolia de sua perda ${ }^{6}$, e a melodia mistura os instrumentos clássicos, relacionados com a erudição do mito grego, e o violão e a batucada, relacionados com a cultura afrodescendente do morro carioca. Para além de ter promovido o encontro entre duas das principais figuras da bossa nova, Orfeu da Conceição parece dialogar com o movimento que surgiria alguns anos mais tarde, ao menos em seu espírito de integração e no cantar alegre da tristeza, sobretudo em termos de entoação, como vimos em "Lamento no morro" - pela ausência, é possível sentir a importância de João Gilberto, sua batida de violão e seu cantar, para a dupla de parceiros. Os arranjos orquestrais, os boleros, a interpretação distanciada, certa dicção trágica do coro ainda estão presentes, afastando a forma que se construiria em seguida.

\section{BLACK ORPHEUS (1989)}

De acordo com Castello (1994), após o sucesso da encenação da peça Orfeu da Conceição no Theatro Municipal do Rio de Janeiro e no Teatro da Lapa, o cenário foi encaixotado para ser levado para uma temporada no Theatro Municipal de São Paulo. Contudo, o caminhão despareceu e, por conta disso, a temporada foi cancelada, tornando essa história um grande mistério.

6 A canção "Mulher, sempre mulher" se distancia dessa denominação porque faz referência a Mira, ex-namorada de Orfeu e ainda apaixonada por ele, que deseja voltar ao seu amor. Os versos finais da canção evidenciam a recusa de Orfeu pelos braços de Mira: "E sendo assim, não insista/ Desista, vá fazendo a pista/ Chore um bocadinho/ E esqueça de mim”. 
Sacha Gordine investe na produção do filme Orfeu negro (I959), com roteiro de Vinicius de Moraes, adaptação de Orfeu da Conceição ao cinema. Entretanto, Gordine acredita que o roteiro é "pouco comercial" e pede a Jacques Viot que o readapte, ou seja, propõe um olhar francês sobre o mito grego no morro carioca. Marcel Camus foi o diretor do filme, um cineasta francês renomado e bastante interessado pela cultura brasileira, visto que dirigiu outros filmes como Os bandeirantes (I959) e Otália da Bahia (I979). Orfeu foi feito no Rio de Janeiro, com belas cenas da cidade e uma fixação um tanto naturalista por mostrar o carnaval e o samba em suas cenas.

Pouco se comenta sobre o filme em O poeta da paixão devido à reação de Vinicius, que teria recusado o filme, quando foi assistir pela primeira vez ao lado de Juscelino Kubitschek, em I959, no Palácio do Catete, abandonando a sala no meio da projeção. Posteriormente Vinicius comentou com amigos que "[e]ssa história de puxar para o exótico não pegou nada bem” (CASTELLO, I994, p. I95). O filme divide opiniões até hoje, entrando de novo em pauta com a refilmagem, de I999, Orfeu, de Cacá Diegues: alguns acreditaram que se tratava de "macumba para turista", como o artista Caetano Veloso (apud FLÉCHET, 2009, p. 5I); já outros afirmavam que Orfeu negro foi importante para a divulgação da cultura e do sincretismo brasileiro, devido à cena bastante documental do terreiro, como o poeta Manuel Bandeira (CRUZ apud ROCHA; CRUZ, 20I5, p. II8). O sucesso de crítica de Orfeu negro foi tão grande que o filme ganhou a Palma de Ouro de melhor filme francês em I959, o Oscar e o Globo de Ouro de melhor filme estrangeiro em I960 e o prêmio British Academy of Film and Television Arts de melhor filme em língua estrangeira em I96I. Anaïs Fléchet, crítica francesa, fala sobre Orfeu negro do ponto de vista europeu (e mundial) e os fatores que levaram o mundo a se encantar pelo filme:

O romance brasileiro de Orfeu e Eurídice agradou por três motivos principais: as imagens coloridas do Rio de Janeiro e da Baía de Guanabara, filmada a partir do morro de Babilônia na zona sul da cidade; o elenco inteiramente negro, no qual se destacam o ex-jogador de futebol Breno Mello, a atriz norte-americana Marpessa Dawn e a jovem Lourdes de Oliveira; e a trilha sonora, incluindo músicas de Luiz Bonfá e Tom Jobim, baterias de escola de samba e pontos de macumba. (FLÉCHET, 2009, p. 45).

O CD da trilha sonora de Orfeu negro se chama Black Orpheus (I989) devido à gravação em Verve/Polygram, uma gravadora estadunidense de jazz que lançou álbuns de grandes nomes do gênero dos EUA, como Ella Fitzgerald. Nos anos I960, a bossa nova exerceu grande influência no jazz estadunidense a partir do Carnegie Hall, em I962, onde vários artistas bossa-novistas se apresentaram. Alguns ficaram nos Estados Unidos, como Tom Jobim, que cinco anos mais tarde gravou Francis Albert Sinatra e Antonio Carlos Jobim (I967), e Sergio Mendes, que já em I964 fixava residência no país e produzia discos de Brazilian music. Tom voltaria ao Brasil na primeira metade da década seguinte.

O álbum Black Orpheus, produzido 30 anos após o lançamento do filme, contém I4 canções retiradas dele, mantidas com algumas falas das personagens e ruídos das cenas. Por ser um filme que acontece durante o período de carnaval, os ruídos são correspondentes aos festejos do feriado. A capa do CD é de cor preta, e o título 
do álbum contém a letra "O" com a imagem do homem fantasiado de esqueleto que persegue Eurídice. No site Discos do Brasil de Maria Luiza Kfouri, nas informações sobre o álbum Black Orpheus, consta uma observação: "A ficha técnica do disco não tem créditos aos músicos e cantores da trilha sonora. Alguns deles foram identificados pela autora desta Discografia e estão assinalados como 'Participações Especiais”" (DISCOS DO BRASIL, s/d). Fléchet (2009) afirma que a batucada é das escolas de samba Mangueira, Portela e Salgueiro, e os cantores são Elizeth Cardoso e Agostinho dos Santos. No ano anterior ao da estreia do filme, foi lançado o álbum Canção do amor demais (I958), considerado o encontro inicial entre Vinicius de Moraes, Tom Jobim e João Gilberto, com interpretação da mesma Elizeth Cardoso e com letras de canções bossa-novistas, como, por exemplo, "Chega de saudade”. Nesse disco, quanto aos arranjos, já podemos ouvir a batida inovadora de João Gilberto, mas não organicamente tratada pelo arranjo de Jobim. No ano seguinte, João Gilberto lança Chega de saudade, agora com as letras de bossa nova, sua batida, sua interpretação e o arranjo adequado para que voz e violão soem como protagonistas e expressando uma vazada leveza moderna.

As composições da trilha sonora do filme são parcerias de Vinicius de Moraes e Tom Jobim e de Luiz Bonfá e Antônio Maria. São I 4 canções no álbum: “Genérico", "A felicidade”, "Frevo de Orfeu”, “O nosso amor", "O nosso amor (tamborim e acordeom)", "Manhã de carnaval”, "Cena do nascer do sol”, "Manhã de carnaval” (instrumental), "Cenas de macumba”, "Samba de Orfeu”, "O nosso amor" (escola de samba), "Manhã de carnaval” (instrumental, segunda versão), "Samba de Orfeu” (instrumental), "Bateria da capela" e "Pot-pourri Manhã de carnaval” (I966). Fléchet (2009) divide as canções em três grupos: a) samba-canção romântico, com as canções "A felicidade" e "Manhã de carnaval"; b) música de carnaval, com "O nosso amor" e "Frevo de Orfeu”; e c) música tradicional afro-brasileira, com as canções de terreiro, os pontos de macumba e umbanda que se referem a Ogum Beira-Mar.

Uma das canções mais famosas do álbum é “A felicidade” (I959), composição de Tom Jobim e Vinicius de Moraes feita para o filme Orfeu negro. Homem e De la Rosa (2013, p. 39) explicam os problemas desse trabalho: "Camus não se limitava a dirigir e, muitas vezes, propunha alterações nas letras. Foi o que aconteceu com 'A felicidade'. Depois de muitas solicitações e alterações, o poeta se irritou e disse que não mudaria mais nada na letra". Nesse livro, os autores colocam lado a lado a letra original e a letra sugerida por Camus, com várias alterações e sugestões. O diretor tentava aproximar a todo custo a letra da música do enredo do filme ${ }^{7}$, como se pode ver nos versos "A minha felicidade está sonhando/ Nos olhos da minha namorada/É como esta noite passando, passando/ Em busca da madrugada/ Falem baixo por favor", que se inserem, por exemplo, na cena em que, depois de uma noite de amor, Orfeu olha Eurídice enquanto ela dorme. Na letra original de Vinicius e Tom, os versos eram "A minha felicidade é uma coisa louca/ Mas tão delicada também/ Tem flores e amores de todas as cores/ Tem ninhos de passarinho/ E tudo de bom e bonito ela tem”.

7 Assim como Vinicius e Tom fizeram para a peça Orfeu da Conceição, já comentado anteriormente neste artigo, mas naquele caso o enredo era de Vinicius. No caso de Orfeu negro, Vinicius fez o argumento, mas o roteiro e a direção do filme não eram dele. 
A letra da canção aborda duas temáticas, a social e a romântica. A primeira, a que corresponde ao refrão e à estrofe sobre a fantasia no período de carnaval, que cada um pode ser o que/quem quiser com o final predeterminado para a quarta-feira de cinzas, último dia do feriado. A felicidade do pobre é ilusão, assim como o carnaval. No filme, há duas cenas bem marcantes sobre isso: a de um senhor que recuperou no penhor uma fantasia de rei e afirmou a Orfeu "Eu sou um rei" (I3:54), e a de Serafina, que só tinha cebolas em casa porque gastou todo seu dinheiro na fantasia de carnaval (I8:3I). A segunda temática corresponde às estrofes sobre metáforas da natureza e sobre o sono da amada. A gota de orvalho escorre como uma lágrima de amor; a pluma, que é a concreção da felicidade, precisa que haja vento constante para poder voar e o silêncio do eu cancional para observar amada enquanto dorme, com o cuidado de não a acordar. Duas temáticas que, no primeiro momento, causam estranhamento por estarem juntas fazem sentido dentro do conjunto do filme, que mostra o amor de Orfeu e Eurídice em um contexto de precariedade social: de carência de alimentos, de ausência de encanamento de água, de felicidade reduzida ao período de carnaval, assim sintetizando, e estereotipando, o ambiente do morro carioca.

Tristeza não tem fim

Felicidade sim

A felicidade é como a gota

De orvalho numa pétala de flor

Brilha tranquila

Depois de leve oscila

E cai como uma lágrima de amor.

A felicidade do pobre parece

A grande ilusão do carnaval

A gente trabalha o ano inteiro

Por um momento de sonho

Pra fazer a fantasia

De rei, ou de pirata, ou da jardineira

E tudo se acabar na quarta-feira.

Tristeza não tem fim

Felicidade sim

A felicidade é como a pluma

Que o vento vai levando pelo ar

Voa tão leve

Mas tem a vida breve

Precisa que haja vento sem parar.

A minha felicidade está sonhando

Nos olhos da minha namorada 
É como esta noite

Passando, passando

Em busca da madrugada

Falem baixo, por favor

Pra que ela acorda alegre como o dia

Oferecendo beijos de amor

Tristeza não tem fim

Felicidade sim.

(Extraído de: HOMEM; DE LA ROSA, 20I3, p. 40).

Complementarmente, a entoação traz algumas características que justificam o êxito da canção. A começar pela reprodução da infinitude da tristeza pelo alongamento da vogal "e", no refrão, enquanto se entoa felicidade de maneira cadenciada e breve. Na estrofe que segue, novamente se afinam letra e melodia, pelo signo da leveza: "A felicidade é como a gota / De orvalho numa pétala de flor". Leveza que se estende até a entoação descendente, que encaminhará o conteúdo social - "E cai como uma lágrima de amor". A partir de então, há uma segunda mudança de tom, que introduz segmentações para representar o lado não lírico do carnaval: "A felicidade do pobre parece”. Nesse contexto, a ascensão de tom dois versos adiante, "A gente trabalha o ano inteiro", soa mais como interpelação do que como desilusão. Em seguida, como encerramento, retorna o motivo melódico da estrofe precedente para encerrar também esse núcleo - "E tudo se acabar na quarta-feira". Na segunda parte da canção, esse tensionamento entre lirismo e sociedade, digamos, se desvanece, mas surge em seu lugar o momento mais intimista e próximo à fala, "falem baixo, por favor", trazendo o ouvinte para o quarto em que a amada dorme, num momento de intensa presentificação, em que o eu cancional e o ouvinte são convocados ao presente da cena íntima dos dois amantes.

Contudo, a canção mais repercutida e interpretada do filme pelo mundo - Frank Sinatra, André Rieu e Stan Getz entre outros artistas já cantaram essa canção - é "Manhã de carnaval", composta por Luiz Bonfá e Antônio Maria. Ela tem uma importância significativa para a consolidação da bossa nova nos EUA (e no mundo) no começo dos anos I960 - abrindo o disco Big Band Bossa Nova (I962), de Stan Getz, em versão instrumental, por exemplo - e foi traduzida para diversas línguas. A canção é um samba-canção romântico com influência do bolero mexicano (FLÉCHET, 2009, p. 47). A temática é da metalinguagem, de um artista que faz a canção para a amada "Nas cordas do meu violão/ Que só teu amor procurou". Os versos "Pois há de haver um dia/ Em que virás" mostram um distanciamento entre o eu cancional e a amada, que na última estrofe explicita que a "A alegria voltou", fazendo menção ao seu retorno esperado. No mito de Orfeu, é com o poder e a beleza de sua música que ele conquista as pessoas e os animais. No filme, enquanto Orfeu toca "Manhã de carnaval" para Zeca e Benedito, Eurídice chega à casa de Serafina, escuta e dança ao ritmo da canção e aparece Orfeu em sua casa, fugindo de mulheres do morro. Eurídice é hipnotizada pela canção. $\mathrm{O}$ amor do casal não é à primeira vista, e sim a "uma primeira ouvida", um amor de outras vidas, transcendental, mas também 
carnal, que vai resultar na noite em que eles passam juntos (ao som de "A felicidade", canção analisada anteriormente).

\author{
Manhã, tão bonita manhã \\ Na vida, uma nova canção \\ Cantando só teus olhos \\ Teu riso, tuas mãos \\ Pois há de haver um dia \\ Em que virás
}

Das cordas do meu violão

Que só teu amor procurou

Vem uma voz

Falar dos beijos perdidos

Nos lábios teus

Canta o meu coração

Alegria voltou

Tão feliz a manhã

Deste amor8.

A versão cantada do álbum é interpretada por Agostinho dos Santos. Ele não economiza nos vibratos, ao estilo samba-canção abolerado, acompanhado por um violão e com melodia bastante passional e branda. A voz de Agostinho e o violão despertam uma melancolia que é quebrada no final, quando acelera o ritmo da canção na última estrofe "Canta meu coração/ Alegria voltou/ Tão feliz a manhã/ Deste amor", como dito anteriormente, que traz a euforia de um amor agora consolidado pela presença da amada. A entoação, aparentemente simples, revela detalhes dos mais deslumbrantes. Na primeira estrofe, canta-se a esperança do ser amado, como se o eu cancional tivesse se esquecido de sua ausência. Na segunda estrofe, especificamente a partir do segundo verso ("Que só teu amor procurou"), melodia e harmonia transformam euforia em certa tristeza de ausência, um recobrar da tristeza, que só se desanuviará em “Canta o meu coração/ Alegria voltou”, em que, como já dito, as vogais ficam mais breves e a sensação é de fim de lamento.

É imensurável a importância do álbum Black Orpheus para a canção popular brasileira, pois ele contém os registros mais antigos de três das escolas de samba mais célebres do Brasil. Marcel Camus contou com a presença em seu filme dos sambistas Djalma Costa e Cartola, que havia sido redescoberto pelo jornalista Sérgio Porto pouco tempo antes, no começo dos anos I950. Cartola foi componente da bateria das escolas de samba e também participou como ator do filme, juntamente com Dona Zica. A cena (I2:I5) se passa no cartório, onde Dona Zica arruma o terno de Cartola (assim como Mira arrumou o de Orfeu), depois o puxa para dar um beijo, e ele afirma "Vem gente!", em tom envergonhado. Além do registro das escolas de samba, o filme

8 Não havendo referências confiáveis, a letra dessa canção foi transcrita com a audição da música. 
documenta diversos tipos de ritmos brasileiros, como o frevo, o samba-canção, a música de macumba, ou seja, canções consideradas mais tradicionais ou "canções de raiz”, ao mesmo tempo que aparecem canções que serão relidas pela bossa nova.

\section{Algumas palavras finais Sobre a Relação entre oS álbuns Orfeu da Conceição e Black Orpheus}

A peça de teatro de Vinicius de Moraes e o filme de Marcel Camus, adaptação da primeira, não contêm nenhuma canção semelhante em seus álbuns, o que os une é a peça Orfeu da Conceição. Acreditamos que esse seja o fator para que este assunto comparativo seja inédito. Como dito anteriormente, Camus encomendou composições de Vinicius, Tom, Bonfá e Antônio Maria e teve liberdade em fazer alterações nas canções para se encaixarem melhor no roteiro do filme. Perrone (apud ROCHA; CRUZ, 20I5) afirma que Gordine, produtor de Orfeu negro, não quis usar as músicas feitas por Tom e Vinicius para Orfeu da Conceição para evitar o pagamento de royalties, então encomendou novas composições para que ele mesmo pudesse registrar e publicar como editor de música, assim lucrando com a metade da receita dos royalties das canções inseridas no filme, enquanto Vinicius e Tom ganharam apenas Io\%. Ou seja, Gordine tentaria lucrar o máximo que conseguisse por conta dos outros (PERRONE apud ROCHA; CRUZ, 20I5, p. 87). Isso é um reflexo da facilidade do europeu em explorar o subdesenvolvido, pois, além de ter ganho os royalties, Camus lucrou devido ao enorme sucesso de bilheteria do filme, pouco sendo repassado a Vinicius de Moraes por conta de seu conhecido hábito de não ler contratos e de não valorizar o dinheiro (VINICIUS, 2005). Talvez a carreira de diplomata já lhe desse o retorno financeiro suficiente para que ele não tivesse que se importar com outras fontes de renda - tensão análoga também está na raiz de Orfeu da Conceição. A mesma liberdade que Sacha Gordine teve para alterar as canções teve anteriormente para solicitar que Jacques Viot alterasse o roteiro do filme feito pelo Vinicius, como já citado, o que aparentemente deixou o poeta mais frustrado do que o não retorno financeiro referente ao filme. Na crônica chamada "Orfeu negro" no livro Para viver um grande amor (20I0), Vinicius conta a experiência de escrever o roteiro para o filme dentro do Chatêau d'Eu, em Paris:

É coisa apaixonante criar um filme. Nesta adaptação construo o filme como eu o faria. Ao contrário de minha peça, em que a "descida aos infernos" de Orfeu situa-se numa gafieira, no $2^{\circ}$ ato, estou transpondo o carnaval carioca para o final do filme, como o ambiente dentro do qual a Morte perseguirá Eurídice. (MORAES, 20Io, p. 70).

Pelo visto, ao escrever a crônica, Vinicius não sabia que isso seria alterado por Viot, pois o inferno do filme se encontra em um terreiro, onde Orfeu se comunica com Eurídice "baixada" no corpo de uma idosa. Na mesma crônica, ele deixa claro o desconhecimento das alterações de Viot: "Estou em pleno carnaval no filme. Procuro dar o máximo de colorido ao roteiro para que, no caso de uma segunda adaptação, o novo roteirista sinta a animação popular em toda a sua vibração" (MORAES, 20Io, p. 7I). 
Voltando às canções, as de Orfeu da Conceição têm influência do bel canto devido ao uso do vibrato de Roberto Paiva nas músicas em samba-canção e ao arranjo, que procura combinar, e não fundir, popular e erudito. Estão muito presentes nas melodias das canções a mistura da orquestra de câmara com instrumentos populares brasileiros, ou seja, fica evidente a mescla entre a cultura europeia e a brasileira. Já Black Orpheus está mais engajado em mostrar a diversidade da cultura brasileira e seus ritmos musicais, apostando no frevo, na música de carnaval, na música de rituais religiosos afro-brasileiros e também no samba-canção, que depois deu origem à bossa nova. Ou seja, o modernismo tardio (AUGUSTO apud ROCHA; CRUZ, 20I5, p. 22) de Orfeu da Conceição tinha como intenção misturar culturas, o clássico da tragédia com o popular do morro brasileiro; em Black Orpheus Camus fez alterações no roteiro e nas composições para que o filme fosse mais atraente ao estrangeiro que pouco conhecia o Brasil, mas as canções do filme são mantidas no álbum. O estrangeiro tinha como referências Carmen Miranda e Zé Carioca. Camus levou a imagem romantizada da favela, do negro brasileiro e do carnaval para o cenário mundial.

Em contrapartida, mesmo as canções sendo diferentes, os compositores se mantiveram em seus papéis. Vinicius e Tom compuseram a maior parte das canções. Em “Certidão de nascimento", crônica musical de Vinicius presente no livro Samba falado (2008), o artista explicita a importância de sua parceria com Tom Jobim para o início da bossa nova, pois a canção marco do gênero é "Chega de saudade" (I958), composição feita depois das canções de Orfeu da Conceição. Tom fez a melodia e deu para Vinicius fazer uma letra, o que lhe foi custoso, mas, quando conseguiu, concluiu que "Era realmente a bossa nova que nascia, a pedir apenas, na sua interpretação, a divisão que João Gilberto descobriria logo depois” (MORAES, 2008, p. I39). Vinicius via a música popular brasileira para além da bossa nova, deixando isso claro em outra crônica, chamada "Abrindo frentes". Charles Perrone afirma:

Agora, com a partida próxima de Carlos Lyra para Nova Iorque, a estada de Tom em Los Angeles e a presença de Baden em Paris, ficaremos com os nossos três mais importantes compositores modernos em postos-chave, garantindo a divulgação do que temos de melhor. E como nenhum dos três é sectário, é fanático da bossa nova, essas novas frentes da música popular brasileira são uma garantia da penetração não só do samba moderno como do tradicional. (PERRONE apud ROCHA; CRUZ, 20I5, p. 90-9I).

A repercussão mundial da bossa nova não beneficiou só esse gênero, mas também o samba tradicional, sendo o samba o ritmo mais difundido do nosso país no exterior. Ao mesmo tempo que a bossa nova atingiu o mundo inteiro, no Brasil ela ficou restrita à classe média e à elite brasileira, com outros compositores e intérpretes pertencentes à alta sociedade, como critica José Ramos Tinhorão: "Esse acontecimento, resultante da incapacidade dos moços desligados dos segredos da percussão popular, de sentirem 'na pele' os impulsos dos ritmos dos negros [...]" (TINHORÃO, 20Io, p. 326).

É evidente que alguns representantes da bossa nova são de classe alta, como Ronaldo Bôscoli e Nara Leão, porém, concomitantemente, João Gilberto veio de Juazeiro, na Bahia, para tentar a vida no Rio de Janeiro, e Tom Jobim passou por apertos financeiros antes de conhecer e fazer parceria com Vinicius de Moraes. Não 
há unanimidade quanto a esse ponto e se faz necessário reconhecer a importância da bossa nova - o samba moderno, mais "americanizado" e contido, mas de enorme poder de síntese entre um país que se modernizado e suas tradições - para o imaginário de cultura brasileira que repercutiu, e repercute, no mundo, não sendo à toa que canções como "Garota de Ipanema" (I962) e "Corcovado" (I959) sejam conhecidas e tocadas em diversos países. Esse é o ponto de chegada dos álbuns: a consolidação da bossa nova nos anos I960, no Brasil e no mundo, como um dos ritmos musicais mais difundidos e admirados. Essa consolidação talvez dependa bastante do sucesso dos Orfeus comentados neste artigo e das canções aqui analisadas.

\section{SOBRE OS AUTORES}

MARINA BONATTO MALKA é mestranda na Universidade Federal do Rio Grande do Sul (UFRGS), bolsista Capes.

E-mail: marinabmalka@gmail.com

CARLOS AUGUSTO BONIFÁCIO LEITE é professor de Literatura Brasileira do Programa de Pós-Graduação em Letras da UFRGS.

E-mail: guto.leite82@gmail.com

\section{REFERÊNCIAS}

ANDRADE, Carlos Drummond de. Claro Enigma. São Paulo: José Olympio, I95I. . O Fazendeiro do ar. São Paulo: José Olympio, I954.

BLANCHOT, Maurice. L'espace littéraire. Paris: Gallimard, 1955.

BRANDÃO, J. de S. Mitologia grega. v. I. Petrópolis: Vozes, I986. . Mitologia grega. v. 2. Petrópolis: Vozes, I987.

CASTELLO, J. Vinicius de Moraes: O Poeta da Paixão - uma biografia. São Paulo: Companhia das Letras, I994. COHN, S.; CAMPOS, S. Vinicius de Moraes - Encontros. Rio de Janeiro: Beco do Azougue, 2007.

DISCOS DO BRASIL. Uma discografia brasileira. Por Maria Luiza Kfouri. 2005. Disponível em: <discosdobrasil.com.br/discosdobrasil >. Acesso em: 5 jun. 2018.

DISCOS do Brasil. Black Orpheus. Disponível em: <discosdobrasil.com.br/discosdobrasil/consulta/detalhe. php?Id_Disco=DIoI9II $>$. Acesso em: Io out. 20I7.

FERRAZ, E. Vinicius de Moraes. São Paulo: Publifolha, 2008. (Folha Explica.)

FLÉCHET, A. Um mito exótico? A recepção crítica de Orfeu negro de Marcel Camus (I959-2008). Significação - Revista de Cultura Audiovisual, v. 36, n. 32, 2009.

. L'exotisme comme objet d'histoire. Paris: Hypothèses, 2008.

GARCIA, Walter. João Gilberto. São Paulo: Cosac Naify, 20I2.I999. 
. Cordialidade, melancolia, modernidade: o trabalho de João Gilberto. Conferência de encerramento. Comunicação oral. In: SEMINÁRIO DE PÓS-GRADUAÇÃO: LITERATURA, SOCIEDADE E HISTÓRIA

DA LITERATURA, 2. Instituto de Letras, Universidade Federal do Rio Grande do Sul, 2017.

HOMEM, Wagner; DE LA ROSA, Bruno. História das canções: Vinicius de Moraes. São Paulo: Leya, 20I3.

INSTITUTO Tom Jobim. Acervo Antonio Carlos Jobim. Disponível em: <http://www.jobim.org/jobim/ handle/20Io/I4698>. Acesso em: I5 out. 2017.

LIMA, Jorge de. A invenção de Orfeu. São Paulo: José Olympio, I952.

MAGALDI, Sábato. Moderna dramaturgia brasileira. São Paulo: Perspectiva, 2010.

MENARD, Renée. Mitologia Greco-Romana. São Paulo: Opus, I99I.

MORAES, Vinicius de. Contracapa do LP Orfeu da Conceição. Gravadora Odeon, I956.

. Samba falado. Rio de Janeiro: Beco do Azougue, 2008.

. Para viver um grande amor. São Paulo: Companhia das Letras, 2010.

. Orfeu da Conceição. São Paulo: Companhia das Letras, 2013.

. Livro de letras. São Paulo: Companhia das Letras, 2015.

PRADO, Décio de Almeida. O teatro brasileiro moderno. São Paulo: Perspectiva, 2009.

ROCHA, André; CRUZ, Cláudio. Orfeu do Vinicius e Cia. Florianópolis: Editora da UFSC, 2015.

SARTRE, Jean-Paul. Orphée Noir. In: SENGHOR, Léopold Sédar. Anthologie de la nouvelle poésie nègre e malgauche de langue française. Paris : Presses Universitaires de France, I948.

SEVERIANO, Jairo. Uma história da música popular brasileira: das origens à modernidade. São Paulo: Editora 34, 2008.

TATIT, Luiz Augusto de Moraes. O cancionista: composição de canções no Brasil. 2. ed. São Paulo: Edusp, 2002.

TINHORÃO, José Ramos. História social da música popular brasileira. São Paulo: Editora 34, 2010.

VINICIUS. Direção de Miguel Faria Jr. Coprodução Globo Filmes, IooI Filmes, 2005. I42 min. Brasil. 